\title{
In silico design and synthesis of hesperitin derivatives as new xanthine oxidase inhibitors
}

\author{
Neelam Malik', Priyanka Dhiman ${ }^{1}$ and Anurag Khatkar ${ }^{2^{*}}$ (i)
}

\begin{abstract}
Background: Hesperitin, a naturally occurring flavonoid was hybridized with phenolic acids to evaluate its potential to inhibit the activity of xanthine oxidase $(X O)$, a key enzyme which catalyses xanthine to uric acid which is found to be associated with gout and many life style related disorders.

Objective: To develop new xanthine oxidase inhibitors from natural constituents along with antioxidant potential.

Method: In this report, we designed and synthesized hesperitin derivatives hybridized with natural phenolic acids to form ester linkage with the help of molecular docking. The synthesized compounds were evaluated for their antioxidant and xanthine oxidase inhibitory potential.

Results: The in vitro xanthine oxidase inhibitory activity and enzyme kinetics studies showed that hesperitin derivatives displayed a potential inhibition against $X O$ in competitive manner with $I C_{50}$ value ranging from 9.0 to $23.15 \mu \mathrm{M}$ and HET4 was revealed as most active derivative. Molecular simulation revealed that new hesperitin derivatives interacted with the amino acid residues SER1080, PHE798, GLN1 194, ARG912, THR1083, ALA1078 and MET1038 located within the active cavity of $\mathrm{XO}$. Results of antioxidant activity revealed that all the derivatives showed very good antioxidant potential.
\end{abstract}

Conclusion: Taking advantage of molecular docking, this hybridization of two natural constituent could lead to desirable xanthine oxidase inhibitors with improved activity.

Keywords: Hesperitin, Xanthine oxidase, Molecular docking, Antioxidant

\section{Introduction}

Contemporary boosts in the prevalence of lifestylerelated health disorders results in triggering of dreadful social health disorders. Gout has recently been renowned as lifestyle-related disorders, even though it was historically denoted as 'the disease of kings' $[1,2]$. The number of sufferers with gout and related painful conditions associated with hyperuricemia in Japan has been significantly amplified during the past 20 years as a consequence of diet alteration along with the accelerated prevalence of metabolic health disorders [3-6]. Gout is

\footnotetext{
*Correspondence: anuragpharmacy@gmail.com; dranuragkhatkarmdurtk@gmail.com

${ }^{2}$ Laboratory for Preservation Technology and Enzyme Inhibition Studies, Department of Pharmaceutical Sciences, M.D. University, Rohtak, Haryana, India

Full list of author information is available at the end of the article
}

an inflammatory disorder which is attributed to elevated amounts and deposition of crystals in the form of uric acid in serum. Uric acid is the end product generated by the catabolism of purine in humans, which is generated by the oxidation of xanthine and hypoxanthine by integral enzyme, xanthine oxidase (XO). For that reason, potent inhibitors of $\mathrm{XO}$ are considered to be excellent candidates for curing gout. Considerable accumulation of serum uric acid appeared to be linked to metabolic syndrome [7-10]. Observing the fact that, increase in the level of serum uric acid level results in insulin resistance, hyperuricemia has been thought to be associated with metabolic syndrome as well as type II diabetes. Additionally, rise in serum uric acid in body is typically associated with the progression of hypertension and renal disorders. As a result, hyperuricemia turns out to be the root cause of life-threatening health disorders; the need arises for the substantially more diverse treatment alternative 
[11-15]. Apart from the multiple adverse reactions, the purine derivative allopurinol and its proactive metabolite, oxypurinol, have long been treated as magnificent preferences for remedial XO inhibition. Keeping in mind the adverse effects produced by purine XO inhibitors; significant efforts were made to explore new, non-purine type $\mathrm{XO}$ inhibitors. Febuxostat, identified as non-purine inhibitor of the xanthine oxidase, is likely to be the most significant example to point out because of its current approval by the FDA [16-22]. An alternate potent category of non-purine kind XO inhibitors is the flavonoids and coumarins, the majority of which have already been identified as effective inhibitors of the enzyme. Furthermore, this enzyme-inhibiting activity is in addition correlated with their renowned anti-oxidant activity in vivo, essentially leading to the established and principally beneficial role of flavonoids in human health. A huge frame of scientific literature on flavonoids as XO inhibitors continues to be reproduced. The paramount system to confer a proper constancy for flavonoids without losing the activity was undertaken. Particularly, the research was focused on the targeted flavonoids designed for preventing the disorders associated with xanthine oxidase. It has been now renowned fact that free radicals play an important role in the oxidation reactions, which is the key source of currently prevalent life-threatening disorders. Hence, derivatization of hesperitin, a flavonoids well known for its antioxidant properties and could be applied as treatment remedy for life-style related diseases was done with phenolic acids [23-30].

In our previous work, molecular mechanistic approach was used to find out potentially active natural constituents from different categories of secondary plant metabolites against xanthine oxidase [31]. The outcomes of the study revealed Hesperitin as one of the most active molecules targeted against xanthine oxidase. These results enforced us to develop more potent derivatives of hesperitin by chemical modification that could be served to treat the disorders caused by XO (Fig. 1).

\section{Experimental}

\section{Chemicals and instrumentation}

For this research, the analytical grade chemicals necessary for synthesis and antioxidant activity were purchased from Hi-media Laboratories. The in vitro evaluation of the human xanthine oxidase inhibitory activity was performed by measuring hydrogen peroxide $\left(\mathrm{H}_{2} \mathrm{O}_{2}\right)$ production from oxidation of xanthine oxidase by the substrate xanthine, utilizing the human xanthine oxidase assay kit (Sigma USA). The progress of reaction was observed through thin layer chromatography (TLC) on $0.25 \mathrm{~mm}$ precoated silica gel plates purchased from Merck, reaction spots were envisaged in iodine compartment and
UV. Melting points were measured using a Sonar melting point apparatus and uncorrected. ${ }^{1} \mathrm{H}$ NMR and ${ }^{13} \mathrm{C}$ NMR spectra were documented in DMSO and deuterated $\mathrm{CDCl}_{3}$ respectively on Bruker Avance II $400 \mathrm{NMR}$ spectrometer at the frequency of $400 \mathrm{MHz}$ using tetramethylsilane standard (downfield) moreover chemical shifts were expressed in ppm $(\delta)$ using the residual solvent line as internal standard. Infrared (IR) spectra were recorded on Perkin Elmer FTIR spectrophotometer by utilizing $\mathrm{KBr}$ pellets system.

\section{Molecular docking}

In silico docking studies was done with integrated Schrodinger software using Glide module for enzyme ligand docking [32]. The 3D crystal structure of xanthine oxidase co-crystallized with salicylic acid was retrieved from Protein Data Bank (PDB ID. 2E1Q). The 3D-structures of hesperitin derived compounds to be docked against $\mathrm{XO}$ were built in maestro building window. Ligand preparation was performed in Ligprep module. The targeted protein structure was further refined in the Protein Preparation Wizard en route to obtain the optimized and chemically accurate protein configuration. For that, the co-crystallized enzyme (XO) was retrieved directly from Protein data bank in maestro panel followed by removal of water molecules, addition of $\mathrm{H}$ atoms, addition of missing side chains and finally minimization was done to obtain the optimized structure. Validation of docking protocol was done by redocking the co-crystallized ligand and RMSD value of $1.2 \AA$ was found which is quite satisfactory to approve the protocol. During the last step of docking, the receptor grid generation tool was utilized to find out the active/binding site for docking and glide docking with extra precision was used to visualize the interaction of protein and ligand.

\section{Synthesis of hesperitin derivatives}

Derivatives of lead compound hesperitin were selected and will be synthesized by established scheme (Scheme 1). The derivatives were synthesized, and reaction was monitored by TLC and spectral characterization was done by IR, NMR and mass spectroscopy.

\section{Procedure for synthesis of hesperitin derivatives}

General procedure for the synthesis of methylated hesperitin Hesperidin was first methylated by methyl iodide in presence of potassium carbonate and dimethyl formamide by stirring along with reflux at $40{ }^{\circ} \mathrm{C}$ for $48 \mathrm{~h}$ to generate methylated hesperidin. Acidolysis of above was done to obtain the methylated hesperitin by refluxing it with $\mathrm{HCl}$ and $95 \%$ ethanol for $4 \mathrm{~h}$. 


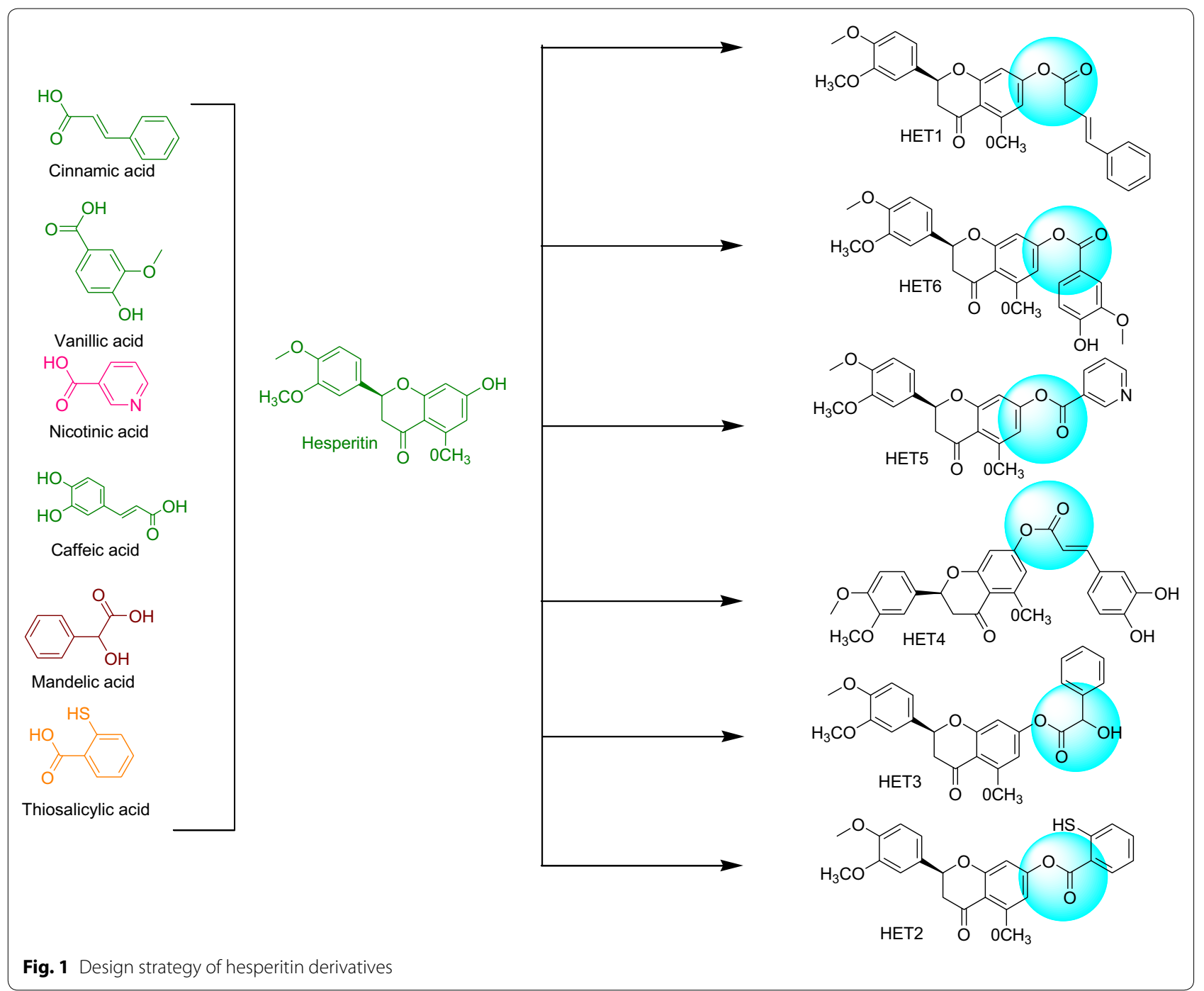

General procedure for the synthesis of ester derivatives of hesperitin Hesperitin $(0.01 \mathrm{~mol})$ was dissolved in diethyl ether and refluxed with different phenolic $(0.01 \mathrm{~mol})$ acid to obtain their ester derivatives.

\section{Spectral data}

HET1: yield $55.6 \% \mathrm{R}_{\mathrm{f}} 0.6$ [mobile phase for TLC-ethyl acetate:methanol:water (15:3:2)] M.pt. (232-233) IR (KBr pelletets) $\mathrm{cm}^{-1} 1633(\mathrm{C}=\mathrm{C}$ str.), $1725(\mathrm{C}=0$ str., ester), 1143 (C-O str.), 1021 (O-CH ${ }_{3}$ str.), ${ }^{1} \mathrm{H}$ NMR (400 MHz, DMSO $\left.-d_{6}\right) \delta 7.53-7.41(\mathrm{~m}, 5 \mathrm{H}), 7.28$ (ddd, $J=7.4,1.5$, $0.6 \mathrm{~Hz}, 1 \mathrm{H}), 7.10(\mathrm{dd}, J=1.5,0.6 \mathrm{~Hz}, 1 \mathrm{H}), 6.97-6.92(\mathrm{~m}$, $2 \mathrm{H}), 6.80(\mathrm{~d}, J=1.5 \mathrm{~Hz}, 1 \mathrm{H}), 6.56(\mathrm{dp}, J=15.1,0.7 \mathrm{~Hz}$, $1 \mathrm{H}), 6.38(\mathrm{dt}, J=15.1,6.1 \mathrm{~Hz}, 1 \mathrm{H}), 5.53(\mathrm{tt}, J=7.0,0.7 \mathrm{~Hz}$, $1 \mathrm{H}), 3.89(\mathrm{~d}, J=8.4 \mathrm{~Hz}, 6 \mathrm{H}), 3.52(\mathrm{dt}, J=6.1,1.0 \mathrm{~Hz}$, $2 \mathrm{H}), 3.32(\mathrm{dd}, J=12.4,7.0 \mathrm{~Hz}, 1 \mathrm{H}), 3.24(\mathrm{dd}, J=12.4$, $7.0 \mathrm{~Hz}, 1 \mathrm{H}), 2.48(\mathrm{~d}, J=0.5 \mathrm{~Hz}, 3 \mathrm{H}){ }^{13} \mathrm{C}$ NMR $(100 \mathrm{MHz}$, chloroform- $d$ ) $\delta 193.30,169.55,162.29,155.19,148.49$, $148.45,141.05,136.54,131.92,131.44,128.51,126.33$, $123.65,120.02,117.33,116.98,113.81,112.91,108.79$, 78.52, 56.36, 56.12, 42.67, 38.44, $30.87 \mathrm{~m} / \mathrm{z}$ found for $\mathrm{C}_{28} \mathrm{H}_{26} \mathrm{O}_{6}: 458\left(\mathrm{M}^{+}\right) 459(\mathrm{M}+1)^{+}$. Anal calcd for $\mathrm{C}_{28} \mathrm{H}_{26} \mathrm{O}_{6}$ : C, 73.35; $\mathrm{H}, 5.72 ; \mathrm{O}, 20.94$ found: $\mathrm{C}, 73.35 ; \mathrm{H}$, $5.75 ; \mathrm{O}, 20.95$.

HET2: yield 72.5\% $\mathrm{R}_{\mathrm{f}} 0.7$ [mobile phase for TLC-ethyl acetate:methanol:water (15:3:2)] M.pt. (225-226) IR (KBr pelletets) $\mathrm{cm}^{-1} 2524$ ( $\mathrm{S}-\mathrm{H}$ str., $\mathrm{Ar}$ ), 1662 ( $\mathrm{C}=\mathrm{C}$ str.), 1710 ( $\mathrm{C}=0$ str., ester), 1160 (C-O str.), $1231\left(\mathrm{O}-\mathrm{CH}_{3}\right.$ str.), ${ }^{1} \mathrm{H}$ NMR $\left(400 \mathrm{MHz}\right.$, DMSO- $\left.d_{6}\right) \delta 8.07(\mathrm{dd}, J=7.4,1.6 \mathrm{~Hz}$, $1 \mathrm{H}), 7.48(\mathrm{dd}, J=7.4,1.6 \mathrm{~Hz}, 1 \mathrm{H}), 7.39(\mathrm{td}, J=7.4,1.6 \mathrm{~Hz}$, $1 \mathrm{H}), 7.31(\mathrm{td}, J=7.4,1.6 \mathrm{~Hz}, 1 \mathrm{H}), 7.18$ (ddd, $J=7.5,1.5$, $0.6 \mathrm{~Hz}, 1 \mathrm{H}), 7.13(\mathrm{dd}, J=1.5,0.6 \mathrm{~Hz}, 1 \mathrm{H}), 6.99-6.93(\mathrm{~m}$, $2 \mathrm{H}), 6.84(\mathrm{~d}, J=1.5 \mathrm{~Hz}, 1 \mathrm{H}), 5.52(\mathrm{tt}, J=7.0,0.6 \mathrm{~Hz}, 1 \mathrm{H})$, $3.73(\mathrm{~d}, J=8.4 \mathrm{~Hz}, 6 \mathrm{H}), 3.36(\mathrm{dd}, J=12.4,7.0 \mathrm{~Hz}, 1 \mathrm{H})$, 


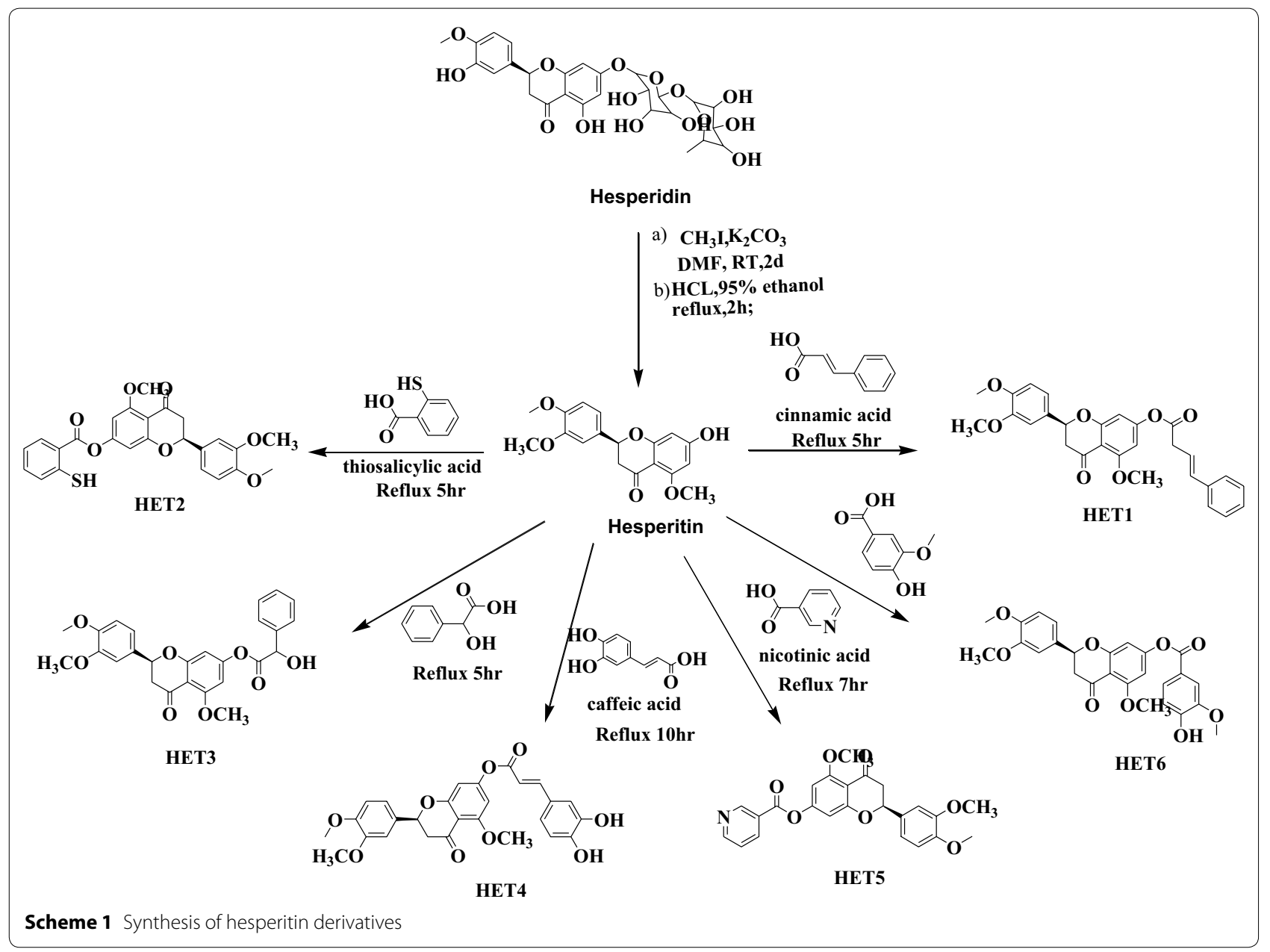

$3.08(\mathrm{dd}, J=12.4,7.0 \mathrm{~Hz}, 1 \mathrm{H}), 2.44(\mathrm{~d}, J=0.5 \mathrm{~Hz}, 3 \mathrm{H}){ }^{13} \mathrm{C}$ NMR (100 MHz, chloroform-d) $\delta$ 197.93, 165.65, 161.30, $150.19,146.85,141.11,138.75,137.97,134.15,133.97$, $130.14,126.30,126.21,126.21,116.08,116.03,114.52$, 114.24, 112.37, 72.20, 58.87, 57.16, 40.47, $22.59 \mathrm{~m} / \mathrm{z}$ found for $\mathrm{C}_{25} \mathrm{H}_{22} \mathrm{O}_{6} \mathrm{~S}: 450\left(\mathrm{M}^{+}\right) 451(\mathrm{M}+1)^{+}$. Anal calcd for $\mathrm{C}_{25} \mathrm{H}_{22} \mathrm{O}_{6} \mathrm{~S}$ : C, 66.65; H, 4.92; O, 21.31; S, 7.12 found: C, 66.65; H, 4.96; O, 21.31; S, 7.15.

HET3: $62.0 \% \mathrm{R}_{\mathrm{f}}$ 05[mobile phase for TLC-ethyl acetate:methanol:water (15:3:2)] M.pt. (220-222) IR (KBr pelletets) $\mathrm{cm}^{-1} 3441$ (O-H str., Ar), 1668 (C=C str.), 1723 (C=0 str., ester), 1124 (C-O str.), $1100\left(\mathrm{O}-\mathrm{CH}_{3}\right.$ str.), ${ }^{1} \mathrm{H}$ NMR (400 MHz, DMSO- $\left.d_{6}\right) \delta 7.42-7.36(\mathrm{~m}, 3 \mathrm{H}), 7.36-$ 7.27 (m, 2H), 7.21 (ddd, J=7.5, 1.5, $0.6 \mathrm{~Hz}, 1 \mathrm{H}), 7.02$ (dd, $J=1.5,0.6 \mathrm{~Hz}, 1 \mathrm{H}), 6.95-6.86(\mathrm{~m}, 2 \mathrm{H}), 6.80(\mathrm{~d}, J=1.5 \mathrm{~Hz}$, $1 \mathrm{H}), 5.54(\mathrm{tt}, J=7.0,0.7 \mathrm{~Hz}, 1 \mathrm{H}), 5.07(\mathrm{t}, J=0.9 \mathrm{~Hz}, 1 \mathrm{H})$, $3.82(\mathrm{~d}, J=8.4 \mathrm{~Hz}, 6 \mathrm{H}), 3.29$ (dd, $J=12.4,7.0 \mathrm{~Hz}, 1 \mathrm{H})$, $3.13(\mathrm{dd}, J=12.4,7.0 \mathrm{~Hz}, 1 \mathrm{H}), 2.43(\mathrm{~d}, J=0.5 \mathrm{~Hz}, 3 \mathrm{H})$ ${ }^{13} \mathrm{C}$ NMR (100 MHz, chloroform-d) $\delta$ 196.13, 171.83, $162.30,156.46,148.49,148.45,141.08,136.97,131.44$, $128.67,127.54,120.02,117.34,117.02,113.81,112.91$,
108.87, 78.52, 73.35, 55.89, 55.88, 44.61, $27.52 \mathrm{~m} / \mathrm{z}$ found for $\mathrm{C}_{26} \mathrm{H}_{24} \mathrm{O}_{7}: 448\left(\mathrm{M}^{+}\right) 449(\mathrm{M}+1)^{+}$. Anal calcd for $\mathrm{C}_{26} \mathrm{H}_{24} \mathrm{O}_{7}:$ C, 69.63; $\mathrm{H}, 5.39 ; \mathrm{O}, 24.97$ found: $\mathrm{C}, 69.66 ; \mathrm{H}$, 5.41; O, 24.97.

HET4: $73.3 \% \mathrm{R}_{\mathrm{f}} 0.6$ [mobile phase for TLC-ethyl acetate:methanol:water (15:3:2)] M.pt. (210-212) IR ( $\mathrm{KBr}$ pelletets) $\mathrm{cm}^{-1} 3424$ (O-H str., Ar), 1635 (C=N str.), 557 (C-Cl str.), 1147 (C-O-C str.), 1511 ( $\mathrm{NO}_{2}$ str.), 1021 (O$\mathrm{CH}_{3}$ str.) ${ }^{1} \mathrm{H}$ NMR (400 MHz, DMSO-d $)_{6} \delta$ 7.71-7.62 (m, 2H), 7.28 (ddd, $J=7.5,1.5,0.6 \mathrm{~Hz}, 2 \mathrm{H}), 7.08-6.99$ $(\mathrm{m}, 4 \mathrm{H}), 6.97(\mathrm{dd}, J=1.5,0.6 \mathrm{~Hz}, 1 \mathrm{H}), 6.94-6.88(\mathrm{~m}, 5 \mathrm{H})$, 6.83-6.77 (m, 6H), $5.51(\mathrm{tt}, J=7.0,0.6 \mathrm{~Hz}, 2 \mathrm{H}), 3.86(\mathrm{~d}$, $J=8.4 \mathrm{~Hz}, 12 \mathrm{H}), 3.27(\mathrm{dd}, J=12.4,7.0 \mathrm{~Hz}, 2 \mathrm{H}), 3.11(\mathrm{dd}$, $J=12.4,7.0 \mathrm{~Hz}, 2 \mathrm{H}), 2.49(\mathrm{~d}, J=0.5 \mathrm{~Hz}, 6 \mathrm{H}) .{ }^{13} \mathrm{C}$ NMR $(100 \mathrm{MHz}$, chloroform-d) $\delta 190.79,164.32,161.30$, $155.87,149.64,149.37,148.55,147.02,145.25,141.08$, $131.44,126.58,122.67,120.02,117.02,116.62,116.36$, $115.86,115.08,113.81,112.91,107.81,75.91,54.86$, 54.03, 44.61, $21.02 \mathrm{~m} / \mathrm{z}$ found for $\mathrm{C}_{27} \mathrm{H}_{24} \mathrm{O}_{8}: 476\left(\mathrm{M}^{+}\right) 477$ $(\mathrm{M}+1)^{+}$. Anal calcd for $\mathrm{C}_{27} \mathrm{H}_{24} \mathrm{O}_{8}: \mathrm{C}, 68.06 ; \mathrm{H}, 5.08$; O, 26.86 found: C, 68.09; H, 5.09; O, 26.88. 
HET5: 71.5\% $\mathrm{R}_{\mathrm{f}} 0.8$ [mobile phase for TLC-ethyl acetate:methanol:water (15:3:2)] M.pt. (219-221) IR ( $\mathrm{KBr}$ pelletets) $\mathrm{cm}^{-1} 1650(\mathrm{C}=\mathrm{N}$ str.), 1627 ( $\mathrm{C}=\mathrm{C}$ str.), 1730 ( $\mathrm{C}=0$ str., ester), 1176 (C-O str.), $1234\left(\mathrm{O}-\mathrm{CH}_{3}\right.$ str.) ${ }^{1} \mathrm{H}$ NMR $\left(400 \mathrm{MHz}, \mathrm{DMSO}-d_{6}\right) \delta 9.17(\mathrm{~d}, J=1.5 \mathrm{~Hz}$, $1 \mathrm{H}), 8.74$ (ddd, $J=7.5,1.5,0.4 \mathrm{~Hz}, 1 \mathrm{H}), 8.14(\mathrm{dt}, J=7.5$, $1.5 \mathrm{~Hz}, 1 \mathrm{H}), 7.51(\mathrm{t}, J=7.5 \mathrm{~Hz}, 1 \mathrm{H}), 7.23(\mathrm{ddd}, J=7.5$, $1.5,1.6 \mathrm{~Hz}, 1 \mathrm{H}), 7.09$ (dd, $J=1.5,0.6 \mathrm{~Hz}, 1 \mathrm{H}), 6.96-6.94$ $(\mathrm{m}, 2 \mathrm{H}), 6.81(\mathrm{~d}, J=1.5 \mathrm{~Hz}, 1 \mathrm{H}), 5.56(\mathrm{tt}, J=7.0,0.6 \mathrm{~Hz}$, $1 \mathrm{H}), 3.76(\mathrm{~d}, J=8.2 \mathrm{~Hz}, 6 \mathrm{H}), 3.37(\mathrm{dd}, J=12.0,7.0 \mathrm{~Hz}$, $1 \mathrm{H}), 3.19(\mathrm{dd}, J=12.2,7.0 \mathrm{~Hz}, 1 \mathrm{H}), 2.39$ (d, $J=7.5 \mathrm{~Hz}$, $3 \mathrm{H}){ }^{13} \mathrm{C}$ NMR (100 MHz, chloroform-d) $\delta$ 197.47, 163.01, $162.30,155.72,153.75,151.34,146.36,141.11,137.45$, $131.44,125.44,123.43,120.02,116.30,114.86,114.82$ 112.37, 104.75, 77.67, 51.86, 51.43, 47.67, $19.82 \mathrm{~m} / \mathrm{z}$ found for $\mathrm{C}_{24} \mathrm{H}_{21} \mathrm{NO}_{6}: 419\left(\mathrm{M}^{+}\right) 420(\mathrm{M}+1)^{+}$. Anal calcd for $\mathrm{C}_{24} \mathrm{H}_{21} \mathrm{NO}_{6}$ : C, 68.73; $\mathrm{H}, 5.05 ; \mathrm{N}, 3.34 ; \mathrm{O}, 22.89$ found: C, 68.75; H, 5.08; N, 3.36; O, 22.89.

HET6: $88.5 \% \mathrm{R}_{\mathrm{f}} 0.6$ [mobile phase for TLC-ethyl acetate:methanol:water (15:3:2)] M.pt. (254-255) IR (KBr pelletets) $\mathrm{cm}^{-1} 3412$ (O-H str., Ar), 1637 (C=C str.), 1715 ( $\mathrm{C}=0$ str., ester), 1196 (C-O str.), $1230\left(\mathrm{O}-\mathrm{CH}_{3}\right.$ str.), ${ }^{1} \mathrm{H}$ NMR (400 MHz, DMSO- $\left.d_{6}\right) \delta 7.61$ (dd, $J=7.5$, $1.5 \mathrm{~Hz}, 1 \mathrm{H}), 7.54(\mathrm{~d}, J=1.5 \mathrm{~Hz}, 1 \mathrm{H}), 7.25$ (ddd, $J=7.4,1.5$, $0.6 \mathrm{~Hz}, 1 \mathrm{H}), 7.01(\mathrm{dd}, J=1.5,0.6 \mathrm{~Hz}, 1 \mathrm{H}), 6.93-6.91(\mathrm{~m}$, $2 \mathrm{H}), 6.85-6.80(\mathrm{~m}, 2 \mathrm{H}), 5.45(\mathrm{tt}, J=7.0,0.6 \mathrm{~Hz}, 1 \mathrm{H}), 3.87$ $(\mathrm{s}, 3 \mathrm{H}), 3.82(\mathrm{~d}, J=8.4 \mathrm{~Hz}, 6 \mathrm{H}), 3.30(\mathrm{dd}, J=12.4,7.0 \mathrm{~Hz}$, $1 \mathrm{H}), 3.20$ (dd, $J=12.4,7.0 \mathrm{~Hz}, 1 \mathrm{H}), 2.50(\mathrm{~d}, J=0.5 \mathrm{~Hz}$, $3 \mathrm{H}){ }^{13} \mathrm{C}$ NMR (100 MHz, chloroform-d) $\delta 186,25,164.43$, $162.94,155.72,147.51,147.42,143.71,143.38,141.11$, $131.44,123.55,121.16,120.00,117.13,117.04,113.81$, 113.20, 112.91, 106.92, 91.15, 56.00, 55.89, 55.88, 43.31, 35.47. $33.31 \mathrm{~m} / \mathrm{z}$ found for $\mathrm{C}_{26} \mathrm{H}_{24} \mathrm{O}_{8}: 464\left(\mathrm{M}^{+}\right) 465$ $(\mathrm{M}+1)^{+}$. Anal calcd for $\mathrm{C}_{26} \mathrm{H}_{24} \mathrm{O}_{8}: \mathrm{C}, 67.23 ; \mathrm{H}, 5.21 ; \mathrm{O}$, 27.56 found: $\mathrm{C}, 67.25 ; \mathrm{H}, 5.23 ; \mathrm{O}, 27.55$.

\section{Evaluation of biological activity In vitro evaluation of xanthine oxidase inhibitory activity}

The method opted to evaluate the inhibitory potential of hesperitin derivatives was a modified protocol of Sigma, done by UV-spectrophotometric method by using xanthine oxidase activity assay kit purchased from sigma (MAK078, sigma-aldrich.co, USA). The colorimetric product obtained in the form of hydrogen peroxide generated during the oxidation of XO was determined by a coupled enzyme technique, measured at $570 \mathrm{~nm}$ in a 96-well plate, using the plate reader $\mathrm{EPOCH}^{\mathrm{TM}}$ "MICROPLATE READER (BIOTEK)". One unit of XO is defined as the amount of enzyme that catalyzes the oxidation of xanthine substrate, yielding $1.0 \mu \mathrm{mol}$ of uric acid and hydrogen peroxide per minute at $25{ }^{\circ} \mathrm{C}$. Reagents used were $44 \mu \mathrm{L}$ of xanthine oxidase assay buffer, $2 \mu \mathrm{L}$ xanthine substrate solution and $2 \mu \mathrm{L}$ of xanthine oxidase enzyme solution. All the solutions mentioned above were mixed to prepare reaction mixture. The different concentrations of synthesized derivatives having final volume $50 \mu \mathrm{L}$ were prepared in dimethyl sulfoxide (DMSO) and added to 96 well plate. To each well $50 \mu \mathrm{L}$ of reaction mix was added and mixed well. After 2-3 min initial measurement was taken. The plates were incubated at $25{ }^{\circ} \mathrm{C}$ taking measurements at every $5 \mathrm{~min}$. Allopurinol served as positive control. Absorbance at different time intervals was noted for further statistical analysis.

\section{In vitro evaluation of antioxidant activity by DPPH method}

The antioxidant potential of hesperitin derivatives was performed by DPPH method evaluated in the form of $\mathrm{IC}_{50}$ estimated using the ELISA plate reader $\mathrm{EPOCH}^{\mathrm{TM}}$ "MICROPLATE READER (BIOTEK)". This method opted for evaluation of free radical scavenging activity of DPPH was base on modified procedure described by Dhiman et al. [33]. The tested compounds were prepared in methanolic solution and reacted with methanolic solution of DPPH at $37{ }^{\circ} \mathrm{C}$. The reaction mixture was prepared in 96-well plate by adding $50 \mu \mathrm{L}$ of sample, $50 \mu \mathrm{L} \mathrm{mL}$ of methanol and $50 \mu \mathrm{L}$ of DPPH solution prepared in $0.1 \mathrm{mM}$ in methanol. The mechanism of action of DPPH assay was based on the fact that DPPH radical get reduced during its reaction with an antioxidant compound and results in changes of color (from deep violet to light yellow). The absorbance was read at $517 \mathrm{~nm}$ for $30 \mathrm{~min}$ at an interval of $5 \mathrm{~min}$ of using ELISA microplate reader. The mixture of methanol $(5.0 \mathrm{~mL})$ and tested compounds $(0.2 \mathrm{~mL})$ serve as blank. Ascorbic acid served as positive control.

\section{Hydrogen peroxide scavenging $\left(\mathrm{H}_{2} \mathrm{O}_{2}\right)$ assay}

To compare and best evaluate the antioxidant potential of newly synthesized hesperitin derivatives, hydrogen peroxide assay was performed by the method described by Patel et al. [34] with some modifications. The solution of $\mathrm{H}_{2} \mathrm{O}_{2}(100 \mathrm{mM})$ was prepared via the adding up different concentrations of synthesized derivatives ranging from 5 to $80 \mu \mathrm{g} / \mathrm{mL}$ to $\mathrm{H}_{2} \mathrm{O}_{2}$ solution $(2 \mathrm{~mL})$, prepared in $20 \mathrm{mM}$ phosphate buffer of $\mathrm{pH}$ 7.4. Finally, the absorbance of $\mathrm{H}_{2} \mathrm{O}_{2}$ was measured at $230 \mathrm{~nm}$ after incubating for $10 \mathrm{~min}$ next to a blank reading of phosphate buffer without $\mathrm{H}_{2} \mathrm{O}_{2}$. For every measurement, a fresh reading of blank was taken to carry out background correction. For control sample containing $\mathrm{H}_{2} \mathrm{O}_{2}$ was scanned for absorbance at $230 \mathrm{~nm}$. Results calculated as percentage of hydrogen peroxide inhibition was estimated by the formula $\left[\left(A_{b}-A_{t}\right) / A_{0}\right] \times 100$, where $A_{b}$ is the absorbance of the control and $A_{t}$ is the absorbance of compounds/ standard taken as L-ascorbic acid $(5-80 \mu \mathrm{g} / \mathrm{mL})$ are shown in Table 3. 
Table 1 Comparison of in vitro activity and molecular docking studies

\begin{tabular}{llll}
\hline Compound & Docking score & $\boldsymbol{\Delta G}(\mathbf{K J} / \mathbf{m o l})$ & $\mathbf{I C}_{\mathbf{5 0}}(\boldsymbol{\mu M})$ \\
\hline HET1 & -10.297 & -61.495 & $18.98 \pm 0.50$ \\
HET2 & -9.106 & -48.846 & $23.15 \pm 1.25$ \\
HET3 & -10.827 & -53.951 & $12.91 \pm 0.72$ \\
HET4 & -13.257 & -77.252 & $09.09 \pm 0.03$ \\
HET5 & -12.148 & -59.473 & $10.76 \pm 0.05$ \\
HET6 & -13.056 & -69.729 & $11.70 \pm 0.01$ \\
Hesperitin & -6.461 & -35.334 & $29.25 \pm 0.12$ \\
Allopurinol & -3.366 & -17.231 & $10.41 \pm 0.72$ \\
\hline
\end{tabular}

\section{Result and discussion Chemistry}

For the synthesis of target compounds, we followed the route as depicted in Scheme 1. Briefly, the Hesperidin the starting material was condensed with methyl iodide and potassium carbonate to afford hesperitin under acid catalyzed conditions. Then ester derivatives were prepared with different natural phenolic acids by refluxing in methanol. Formation of ester was confirmed by formation of ester $\mathrm{C}=\mathrm{O}$ linkage between hesperitin and phenolic acids. Other spectral characterization was also found in agreement.

\section{Molecular docking}

To rationalize the structure activity relationship observed in this research and to foreknow the potential interaction of the synthesized compounds with $\mathrm{XO}$, molecular simulation studies were carried out using Schrödinger suite (Schrödinger Release 2018-2, Schrödinger, LLC, New York, NY, 2018). The crystal structure of xanthine oxidase with PDB code 2E1Q was adopted for the docking calculations. Based on the docking score and binding energy calculation, top ranking derivatives were established and compared with the $\mathrm{IC}_{50}$ calculated from in vitro activity (Table 1). The consequential output of ligand docking in form of docked confirmation exposed the significant binding and revealed that all the in vitro synthesized hesperitin derivatives screened by in silico method could be well fitted into the active cavity/binding site of xanthine oxidase making potential binding interactions with the amino acid of nearby residues in close proximity of binding site. An exhaustive per-residue interaction between the xanthine oxidase and synthesized hesperitin derivatives was analyzed to reveal the binding patterns in the cavity. However, to concise the discussion illustration only for the top two compounds along with the native structure hesperitin and standard drug allopurinol and the results are summarized in Table 1.

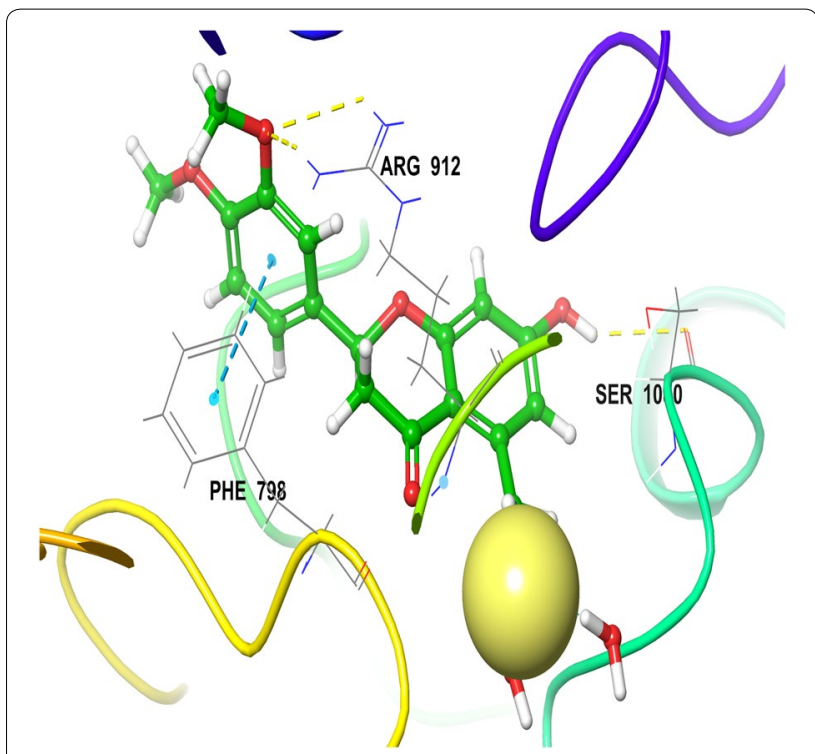

Fig. 2 3D view of hesperitin in the active site of xanthine oxidase

Detailed visualization of hesperitin binding poses showed various interactions including hydrophobic, polar and electropositive interactions. The dimethoxy phenyl ring of hesperitin formed a $\pi-\pi$ stacking with hydrophobic amino acid PHE798 of XO. This $\pi-\pi$ interaction was missing in all the synthesized compounds including most active compound and Allopurinol. From this observation, it could be concluded that pi-pi stacking might be essential for the stability of hesperitin not for the activity. Visual inspection of chroman-4-one moiety of hesperitin elucidates a narrow channel of polar amino acids (GLN767, SER1080, THR1083, GLN1194) surrounded in close proximity of HET4 and forms a H-bond SER 1080 amino acid. Another interesting electropositive interaction was observed between dimethoxy phenyl ring positively charged ARG912 in close vicinity of MOS 1328 (molybdenum atom) which formed a H-bond with GLN767 (Fig. 2).

The minimized docked conformation of the most active compound HET4 captured in the potentially binding site of XO displayed that HET4 binds at the similar coordinates (Fig. 3) as hesperitin building compact acquaintances with the binding site amino acids by important bonded and non-bonded interactions. The glide score was found to be -13.257 in comparison to hesperitin (dock score -6.461 ) producing an overall binding energy of $-77.252 \mathrm{kcal} / \mathrm{mol}$. The Vander Waals forces contribute maximum share $(-48.709)$ of binding energy and found to be much established than the electrostatic interactions $(-6.482)$ when comparing the overall interactive forces of HET4 against XO. In accordance to molecular docking predictions, the dihydroxyphenyl acrylate 

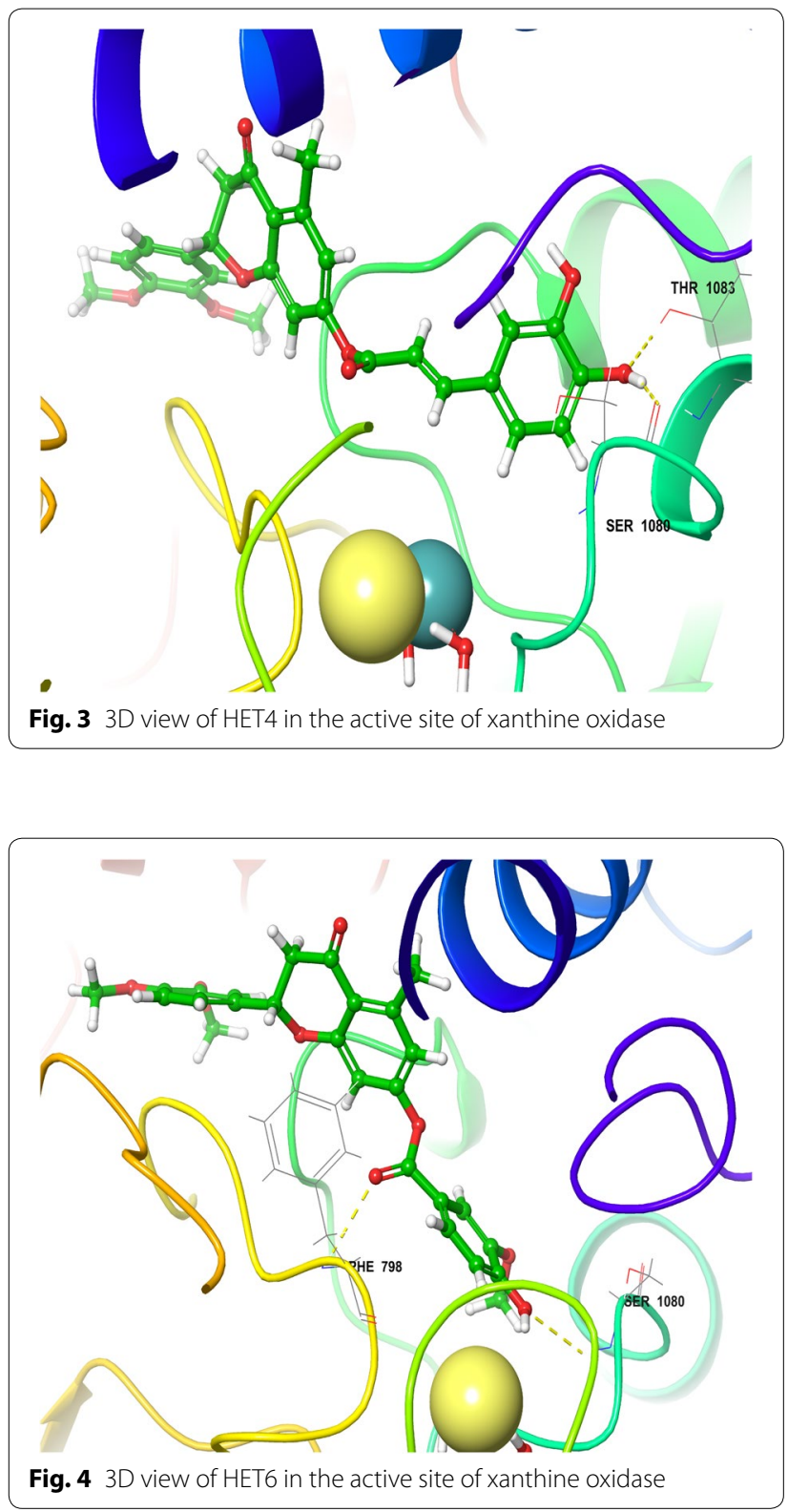

moiety of HET4 fits within the proteolytic site with good affinity of the xanthine oxidase and is involved, through its hydroxyl oxygen, forming two hydrogen bonds with the polar amino acids SER1080 and THR1083. The oxochroman-7-yl portions, although not forming any direct connections with the neighboring enzyme residues, emerges significant to anchor the centralized part of the ligand defined by the important hydrophobic interactions (ALA1198, PHE798 and MET1038). A very similar binding pattern was exhibited by HET6 (Fig. 4), which retains the inhibitory effect of HET4 possessing a glide score -13.056 and binding energy $-69.729 \mathrm{kcal} / \mathrm{mol}$ forming two H-bond with SER1080 and PHE798. The loss of observed activity may be contributed to the missing hydrogen bond in HET6 because of different phenolic acid substitution in HET4. In case of Allopurinol, the active site residues surrounding ligand were almost similar and placed near to MOS 1328. The hydrogen bond was observed between purine ring of Allopurinol and GLN1194 (Fig. 5).

\section{In vitro xanthine oxidase inhibitory activity}

In order to monitor the efficacy of hybridized hesperitin and phenolic acid derivatives, xanthine oxidase inhibitory activity was determined using XO Activity Assay Kit purchased from Sigma-aldrich Co. Allopurinol (positive control) reported to inhibit xanthine oxidase was also analysed in similar environmental conditions to make a comparison with synthesized derivatives. The inhibition ratios revealed the xanthine oxidase inhibitory activity of the synthesized hesperitin derivatives and the results are compiled in Table 1 and compared with results of molecular docking. Phenolic acid derived hesperitin derivatives exhibited remarkable activity comparable to the positive control. All the compounds of this series were effective with $\mathrm{IC}_{50}$ values ranging from 09.0 to $23.15 \mu \mathrm{M}$. Based on the in vitro activity; it was observed that ester linkage developed from caffeic acid and hesperitin (HET4) comes out most active derivative among all the synthesized compounds showing $\mathrm{IC}_{50}$ value $09.094 \pm 0.03 \mu \mathrm{M}$. Compound HET6 having vanillic acid and HET5 having nicotinic acid substitution also exhibited potential inhibitory activity with an $\mathrm{IC}_{50}$ value of $11.702 \pm 0.01 \mu \mathrm{M}$ and $10.769 \pm 0.05 \mu \mathrm{M}$ respectively. All the derivatives showed better activity than hesperitin establishing the importance of ester linkage formed in synthesized derivatives. The results of in vitro activity were found to in concordance of docking studies revealing the significance of in silico screening.

\section{Enzyme kinetic analysis for XO-inhibitory activity}

To determine the XO-inhibitory mechanisms of newly synthesized derivatives, we carried out kinetic studies of most active compound HET4 using Graph pad prism software. Firstly Michaelis-Menten curve was plotted for the enzyme activity at different concentrations of HET4 against different concentration of xanthine substrate (Fig. 6).

Then double reciprocal plot (Lineweaver-Burk) analysis was done in the presence $(0.25,0.5$, and $1.0 \mu \mathrm{M})$ and absence of HET4 from in vitro data generated during the oxidation of xanthine in presence of xanthine oxidase (Fig. 7). The $x$ - and $y$-axis intercepts of the LineweaverBurk plot were utilized to calculate $\mathrm{K}_{\mathrm{m}}$ and $\mathrm{V}_{\max }$ values of HET4 at different concentrations (Table 2). 

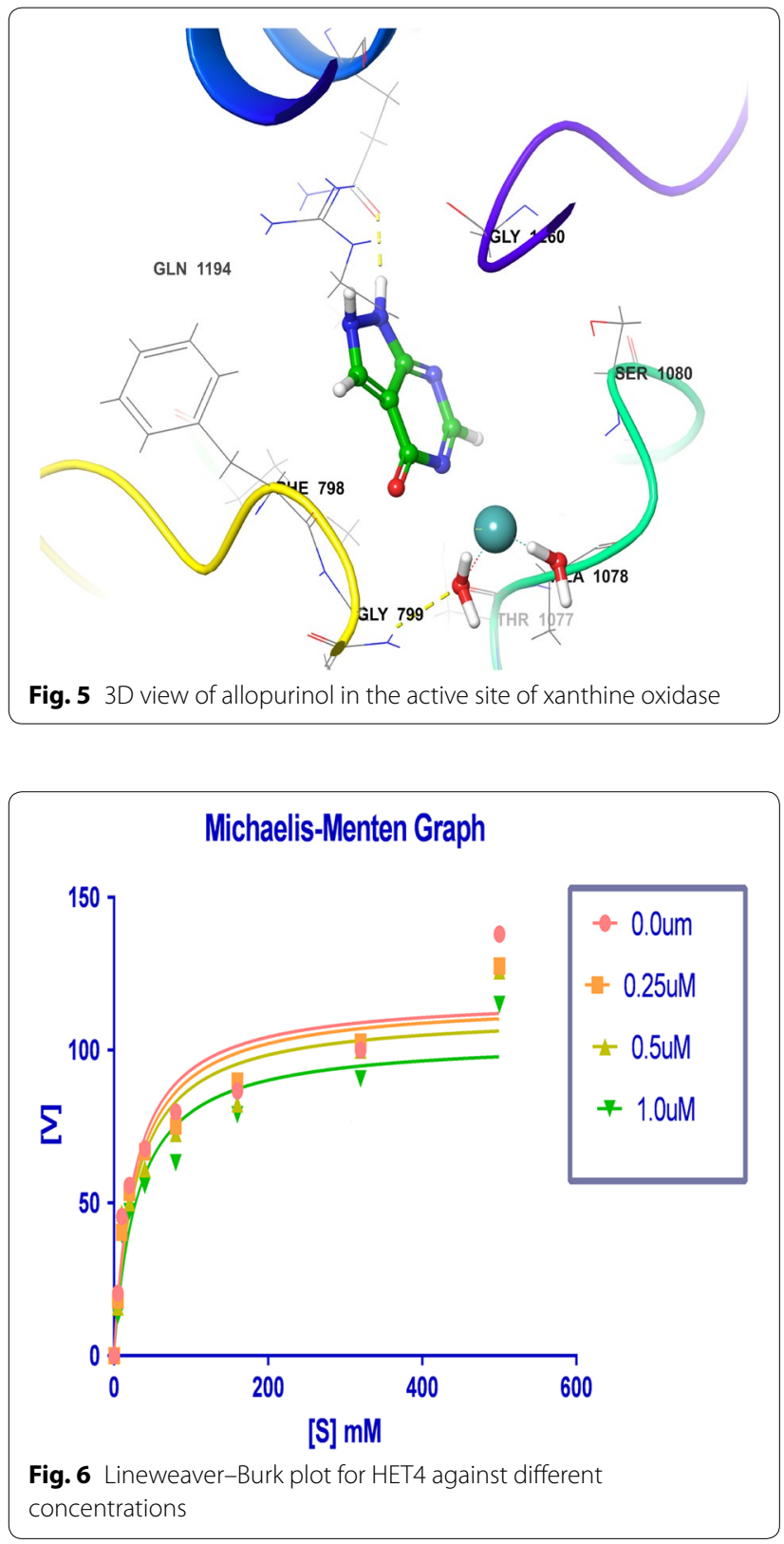

A concentration-dependent decrease of $V_{\max }$ was predicted in contrast to $K_{m}$ value which was found to increasing when concentration of HET4 was increased. The intersection of linear straight lines drawn against each concentration was located at same point, suggesting that HET4 reacts in competitive manner during the inhibition of xanthine oxidase.

In vitro assay for free radical scavenging by DPPH and hydrogen peroxide method

The antioxidant potential of newly synthesized compounds was evaluated by DPPH and Hydrogen peroxide

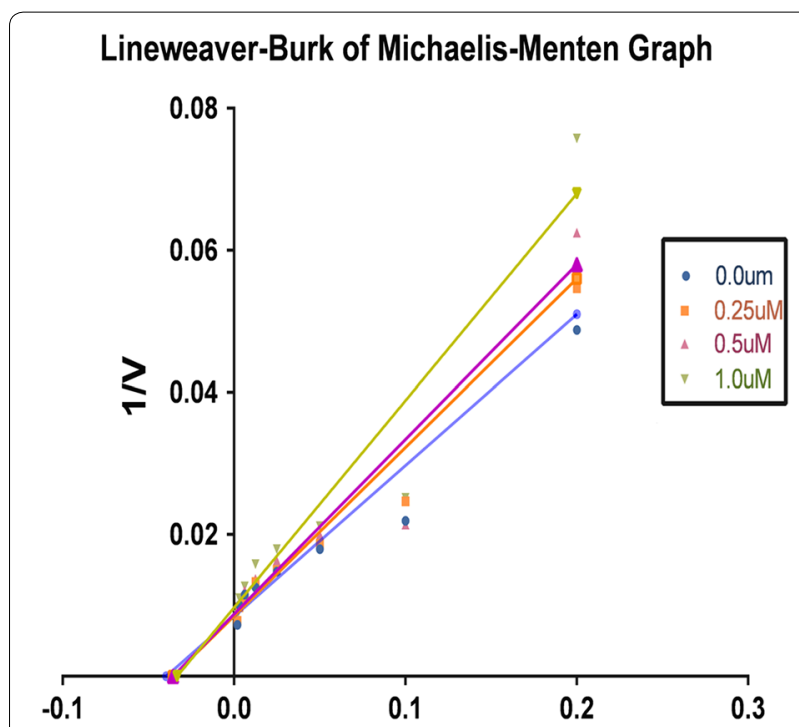

Fig. 7 Michaelis-Menten curve for HET4 at different concentrations

Table $2 K_{m}$ and $V_{\max }$ values of xanthine oxidase at different concentrations of HET4

\begin{tabular}{llll}
\hline S. no. & $\begin{array}{l}\text { Conc. of HET4 } \\
(\mu \mathrm{M})\end{array}$ & $\mathrm{K}_{\mathbf{m}}(\boldsymbol{\mu M})$ & $\mathbf{V}_{\max }(\mu \mathrm{mol} / \mathbf{m i n})$ \\
\hline 1 & 0.0 & 25.21 & 117.6 \\
2 & 0.25 & 27.91 & 116.4 \\
3 & 0.5 & 28.02 & 112.2 \\
4 & 1.0 & 30.08 & 103.7 \\
\hline
\end{tabular}

Table 3 Antioxidant activity of synthesized derivatives by DPPH and $\mathrm{H}_{2} \mathrm{O}_{2}$ assay

\begin{tabular}{lcl}
\hline Comp. & $\begin{array}{l}\mathrm{IC}_{\mathbf{5 0}}(\mu \mathrm{M}) \pm \mathrm{SEM} \\
\text { (DPPH assay) }\end{array}$ & $\begin{array}{l}\mathrm{IC}_{\mathbf{5 0}}(\boldsymbol{\mu M}) \pm \mathrm{SEM} \\
\text { (hydrogen peroxide } \\
\text { assay }\end{array}$ \\
\hline HET1 & $11.117 \pm 0.03$ & $12.693 \pm 0.41$ \\
HET2 & $06.714 \pm 0.15$ & $8.5473 \pm 0.06$ \\
HET3 & $0.593 \pm 0.25$ & $03.322 \pm 0.01$ \\
HET4 & $01.633 \pm 0.01$ & $04.642 \pm 0.03$ \\
HET5 & $04.821 \pm 0.06$ & $06.367 \pm 0.26$ \\
HET6 & $07.113 \pm 0.13$ & $07.510 \pm 0.02$ \\
Hesperitin & $12.895 \pm 0.20$ & $14.425 \pm 0.14$ \\
Ascorbic acid & $22.195 \pm 0.08$ & \\
\hline
\end{tabular}

SEM standard error of the mean

radical assay. The comparative analysis of $\mathrm{IC}_{50}$ values for both the assays was done and the results were found to be impressive (Table 3).

The results evinced a noteworthy inhibition of $\mathrm{DPPH}$ almost all the compounds when compared with the positive control ascorbic acid (Fig. 8). In case of DPPH assay compound HET4 was demonstrated 


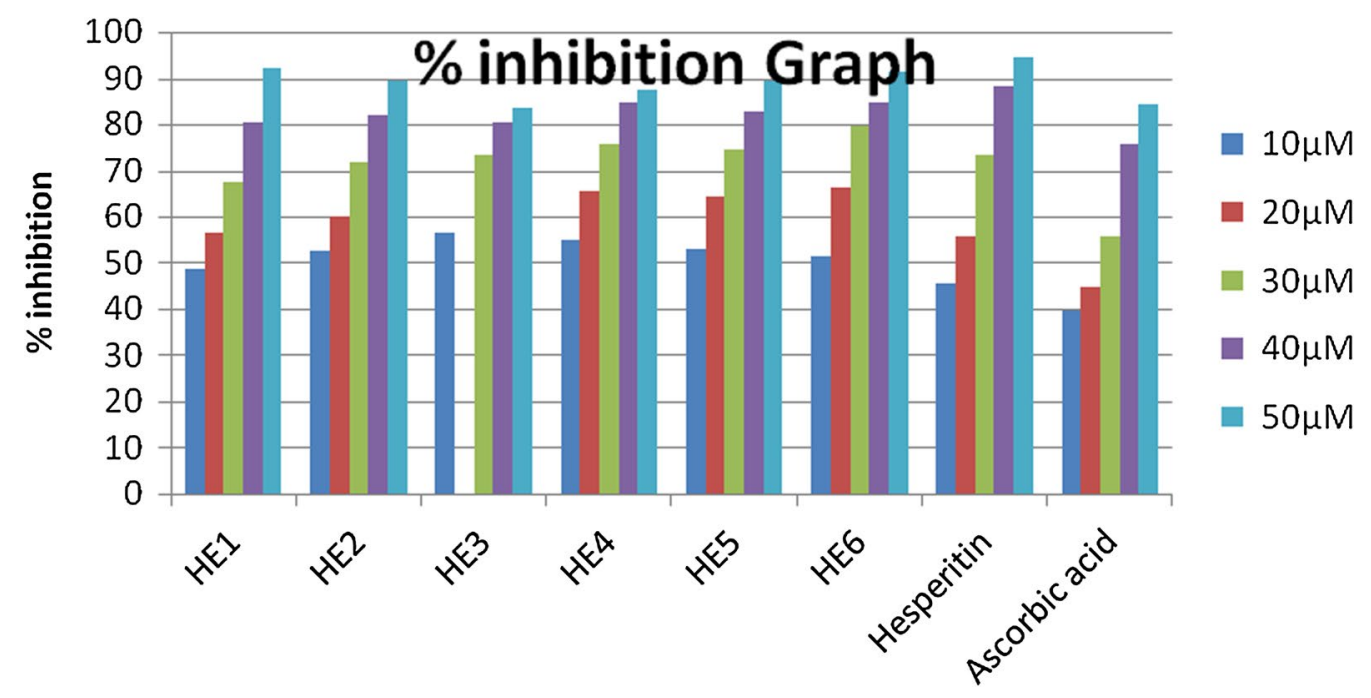

Fig. 8 Percentage inhibition graph of synthesized compounds in DPPH assay

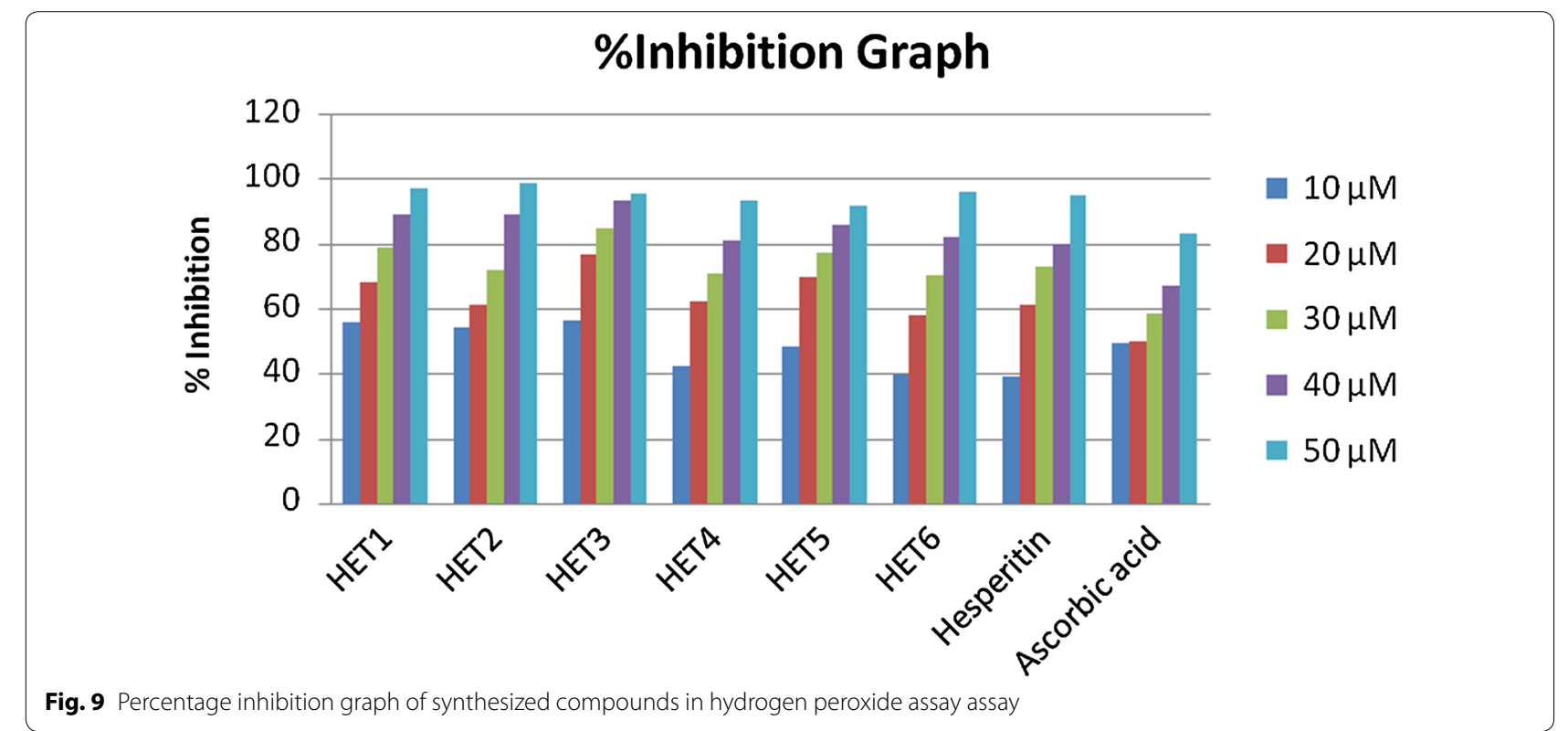

as most potent compound against oxidative stress caused because of free radicals having an $\mathrm{IC}_{50}$ value of $01.633 \pm 0.01 \mu \mathrm{M}$. Along with this compound HET5 also showed very good antioxidant potential with an $\mathrm{IC}_{50}$ value of $04.821 \pm 0.06 \mu \mathrm{M}$.

When the detailed structure activity relationship was developed between these compounds, it was concluded that both the compounds have an aromatic $\mathrm{OH}$ group attached to the phenyl acrylate moiety. Conversely, during the analysis of hydrogen peroxide assay all the compounds of ester series of hesperitin showed very good antioxidant potential having $\mathrm{IC}_{50}$ in range of
$03.322 \pm 0.01$ to $11.117 \pm 0.03$ (Fig. 9). Compound HET3 having mandelic acid substitution showed potential antioxidant activity among all the derivatives. Along with this caffeic acid substituted HET4 also showed very good scavenging activity with an $\mathrm{IC}_{50}$ value of $04.642 \pm 0.03$.

\section{Conclusion}

Starting from the structures of hesperitin as anti-XO hit previously identified, different hybrid ester of natural phenolic acids was designed and synthesized to explore the structure-activity relationships associated with these 
xanthine oxidase inhibitors along with their antioxidant potential. Different structural elements were identified as essential for antioxidant and anti-XO properties, such as the presence of $\mathrm{OH}$ substituent on aromatic ring (HET4 and HET6), presence of nicotinic ring linker and the overall length and rigidity of the methyl-4-oxochroman-7-yl scaffold. The newly synthesized derivatives with anti-oxidant and ani-XO $\mathrm{IC}_{50}$ values in the low micro molar range and good selectivity indexes were identified. Molecular docking provides an improved trail to design the new molecules with an avant-garde stability and potency. This hybridization of two natural constituent could lead to desirable xanthine oxidase inhibitors with improved activity and lower side effects.

\section{Authors' contributions}

NM and AK have designed, synthesized and carried out the XO inhibitory and antioxidant activity and PD, have carried out the docking simulations with in silico ADMET studies. All authors read and approved the final manuscript.

\section{Author details}

${ }^{1}$ Department of Pharmaceutical Sciences, M.D. University, Rohtak 124001, India. ${ }^{2}$ Laboratory for Preservation Technology and Enzyme Inhibition Studies, Department of Pharmaceutical Sciences, M.D. University, Rohtak, Haryana, India.

\section{Acknowledgements}

The authors are extremely grateful to the Head, Department of Pharmaceutical Sciences, M. D. University, Rohtak for providing fundamental facilities to carry out this investigation study. The authors are also thankful to Dr. Vinod Devaraji Application Scientist Schrödinger LLC for his sustain guidance to carry out the dry lab work.

\section{Competing interests}

The authors declare that they have no competing interests.

\section{Availability of data and materials}

The datasets used and/or analyzed during the current study are available from the corresponding author on reasonable request.

\section{Funding}

No funding received for this research work from outside sources.

\section{Publisher's Note}

Springer Nature remains neutral with regard to jurisdictional claims in published maps and institutional affiliations.

Received: 7 December 2018 Accepted: 6 April 2019

Published online: 16 April 2019

\section{References}

1. Masuda T, Nojima S, Miura Y, Honda S, Masuda A (2015) An oxidative coupling product of luteolin with cysteine ester and its enhanced inhibitory activity for xanthine oxidase. Bioorg Med Chem Lett 25(16):3117-3119

2. Chen CJ, Tseng CC, Yen JH, Chang JG, Chou WC, Chu HW, Chang SJ, Liao WT (2018) ABCG2 contributes to the development of gout and hyperuricemia in a genome-wide association study. Sci Rep 8(1):3137

3. Miao Z, Li C, Chen Y, Zhao S, Wang Y, Wang Z, Chen X, Xu F, Wang F, Sun R, $\mathrm{Hu} J$ (2008) Dietary and lifestyle changes associated with high prevalence of hyperuricemia and gout in the Shandong coastal cities of Eastern China. J Rheumatol 35(9):1859-1864
4. Smyth CJ (1975) Disorders associated with hyperuricemia. Arthritis Rheum 18(S1):713-720

5. Zhu Y, Pandya BJ, Choi HK (2011) Prevalence of gout and hyperuricemia in the US general population: the national health and nutrition examination survey 2007-2008. Arthritis Rheum 63(10):3136-3141

6. Wallace KL, Riedel AA, Joseph-Ridge N, Wortmann R (2004) Increasing prevalence of gout and hyperuricemia over 10 years among older adults in a managed care population. J Rheumatol 31(8):1582-1587

7. Maiuolo J, Oppedisano F, Gratteri S, Muscoli C, Mollace V (2016) Regulation of uric acid metabolism and excretion. Int J Cardiol 15(213):8-14

8. Chen C, Lü JM, Yao Q (2016) Hyperuricemia-related diseases and xanthine oxidoreductase (XOR) inhibitors: an overview. Med Sci Monit 22:2501

9. Battelli MG, Bortolotti M, Polito L, Bolognesi A (2018) The role of xanthine oxidoreductase and uric acid in metabolic syndrome. Biochim Biophys Acta Mol Basis Dis. https://doi.org/10.1016/j.bbadis.2018.05.003

10. Borghi C, Desideri G (2016) Urate-lowering drugs and prevention of cardiovascular disease: the emerging role of xanthine oxidase inhibition. Hypertension 67:496-498

11. Li GX, Jiao XH, Cheng XB (2018) Correlations between blood uric acid and the incidence and progression of type 2 diabetes nephropathy. Eur Rev Med Pharmacol 22:506-511

12. Johnson RJ, Kang DH, Feig D, Kivlighn S, Kanellis J, Watanabe S, Tuttle KR, Rodriguez-Iturbe B, Herrera-Acosta J, Mazzali M (2003) Is there a pathogenetic role for uric acid in hypertension and cardiovascular and renal disease? Hypertension 41(6):1183-1190

13. Dawson J, Walters M (2006) Uric acid and xanthine oxidase: future therapeutic targets in the prevention of cardiovascular disease? $\mathrm{Br} J$ Clin Pharmacol 62(6):633-644

14. Kang DH, Nakagawa T, Feng L, Watanabe S, Han L, Mazzali M, Truong L, Harris R, Johnson RJ (2002) A role for uric acid in the progression of renal disease. J Am Soc Nephrol 13(12):2888-2897

15. Kanbay M, Segal M, Afsar B, Kang DH, Rodriguez-Iturbe B, Johnson RJ (2013) The role of uric acid in the pathogenesis of human cardiovascular disease. Heart. https://doi.org/10.1136/heartjnl-2012-302535

16. Elion GB, Kovensky A, Hitchings GH, Metz E, Rundles RW (1966) Metabolic studies of allopurinol, an inhibitor of xanthine oxidase. Biochem Pharmacol 15(7):863-880

17. Siu YP, Leung KT, Tong MK, Kwan TH (2006) Use of allopurinol in slowing the progression of renal disease through its ability to lower serum uric acid level. Am J Kidney Dis 47(1):51-59

18. Becker MA, Schumacher HR Jr, Wortmann RL, MacDonald PA, Eustace D, Palo WA, Streit J, Joseph-Ridge N (2005) Febuxostat compared with allopurinol in patients with hyperuricemia and gout. N Engl J Med 353(23):2450-2461

19. Hande KR, Noone RM, Stone WJ (1984) Severe allopurinol toxicity: description and guidelines for prevention in patients with renal insufficiency. Am J Med Sci 76(1):47-56

20. Arellano F, Sacristán JA (1993) Allopurinol hypersensitivity syndrome: a review. Ann Pharmacother 27(3):337-343

21. Becker MA, Schumacher HR, Espinoza LR, Wells AF, MacDonald P, Lloyd E, Lademacher C (2010) The urate-lowering efficacy and safety of febuxostat in the treatment of the hyperuricemia of gout: the CONFIRMS trial. Arthritis Res Ther 12(2):R63

22. Takano Y, Hase-Aoki K, Horiuchi H, Zhao L, Kasahara Y, Kondo S, Becker MA (2005) Selectivity of febuxostat, a novel non-purine inhibitor of xanthine oxidase/xanthine dehydrogenase. Life Sci 76(16):1835-1847

23. Borges F, Fernandes E, Roleira F (2002) Progress towards the discovery of xanthine oxidase inhibitors. Curr Med Chem 9(2):195-217

24. Lin S, Zhang G, Liao Y, Pan J, Gong D (2015) Dietary flavonoids as xanthine oxidase inhibitors: structure-affinity and structure-activity relationships. J Agric Food Chem 63(35):7784-7794

25. Van Acker SA, Tromp MN, Griffioen DH, Van Bennekom WP, Van Der Vijgh WJ, Bast A (1996) Structural aspects of antioxidant activity of flavonoids. Free Radic Biol Med 20(3):331-342

26. Heim KE, Tagliaferro AR, Bobilya DJ (2002) Flavonoid antioxidants: chemistry, metabolism and structure-activity relationships. J Nutr Biochem 13(10):572-584

27. Boumendjel A, Mariette AM, Bresson-Rival D, Perrier E (2003) Hesperitin esters: highly stable flavanones with both free radical scavenging and anti-elastase activities. Pharm Biol 41(7):546-549 
28. Zou SJ, Yu Zh, Xu SJ, Xu Y, Ma YL (2013) Scavenging activities of free radical of hesperidin and hesperitin. Acta Chin Med Pharmacol 1:024

29. Fais A, Era B, Asthana S, Sogos V, Medda R, Santana L, Uriarte E, Matos MJ, Delogu F, Kumar A (2018) Coumarin derivatives as promising xanthine oxidase inhibitors. Int J Biol Macromol 120:1286-1293

30. Wang Y, Zhang G, Pan J, Gong D (2015) Novel insights into the inhibitory mechanism of kaempferol on xanthine oxidase. J Agric Food Chem 63(2):526-534

31. Malik N, Dhiman P, Khatkar A (2017) In-silico design and ADMET studies of natural compounds as inhibitors of xanthine oxidase $(X O)$ enzyme. Curr Drug Metab 18(6):577-593

32. Friesner RA, Banks JL, Murphy RB, Halgren TA, Klicic JJ, Mainz DT, Repasky MP, Knoll EH, Shelley M, Perry JK, Shaw DE (2004) Glide: a new approach for rapid, accurate docking and scoring. 1. Method and assessment of docking accuracy. J Med Chem 47(7):1739-1749

33. Dhiman P, Malik N, Verma PK, Khatkar A (2015) Synthesis and biological evaluation of thiazolo and imidazo $N$-(4-nitrophenyl)-7-methyl5-aryl-pyrimidine-6 carboxamide derivatives. Res Chem Intermed 41(11):8699-8711

34. Patel A, Patel A, Patel A, Patel NM (2010) Determination of polyphenols and free radical scavenging activity of Tephrosia purpurea linn leaves (Leguminosae). Pharmacogn Res 2(3):152
Ready to submit your research? Choose BMC and benefit from:

- fast, convenient online submission

- thorough peer review by experienced researchers in your field

- rapid publication on acceptance

- support for research data, including large and complex data types

- gold Open Access which fosters wider collaboration and increased citations

- maximum visibility for your research: over 100M website views per year

At BMC, research is always in progress.

Learn more biomedcentral.com/submissions 